\title{
POSSIBLE ROLE OF N-METHYL-D-ASPARTATE RECEPTORS IN PHYSIOLOGY AND PATHOPHYSIOLOGY OF CARDIOVASCULAR SYSTEM
}

Ivan Srejovic ${ }^{1}$, Vladimir Jakovljevic ${ }^{1}$, Vladimir Zivkovic ${ }^{1}$ and Dragan Djuric ${ }^{2}$

${ }^{1}$ Department of Physiology, Faculty of Medical Sciences, University of Kragujevac, Kragujevac, Serbia

${ }^{2}$ Institute of Medical Physiology "Richard Burian", Faculty of Medicine, University of Belgrade, Belgrade, Serbia

\author{
MOGUĆA ULOGA N-METIL-D-ASPARTATNIH RECEPTORA \\ U FIZIOLOGIJI I PATOFIZIOLOGIJI KARDIOVASKULARNOG SISTEMA \\ Ivan Srejović1, Vladimir Jakovljević1, Vladimir Živković1 i Dragan Djurić2 \\ ${ }^{1}$ Katedra za fiziologiju, Fakultet medicinskih nauka, Univerzitet u Kragujevcu, Kragujevac, Srbija \\ ${ }^{2}$ Institut za medicinsku fiziologiju "Rihard Burian”, Medicinski fakultet, Univerzitet u Beogradu, Beograd, Srbija
}

Received / Primljen: 27. 03. 2017.

Accepted / Prihvaćen: 28. 03. 2017.

\begin{abstract}
$N$-methyl-D-aspartate (NMDA) receptors belong to ionotropic glutamate receptor family, together with $\alpha$-amino-3hydroxy-5-methyl-4-isoxazolepropionic acid (AMPA) receptors, kainite receptors and $\delta$-receptors. All of these receptors are tetramers composed of four subunits. NMDA receptors have several unique features in relation to other ionotropic glutamate receptors: requirement for simultaneous action of two coagonists, glutamate and glycine; dual control of receptor activation, ligand-dependent (by glutamate and glycine) and voltage-dependent $\left(\mathrm{Mg}^{2+}\right.$ block) control; and influx of considerable amounts of $\mathrm{Ca}^{2+}$ following receptor activation. Increasing number of researches deals with physiological and pathophysiological roles of NMDA receptors outside of nerve tissues, especially in the cardiovascular system. NMDA receptors are found in all cell types represented in cardiovascular system, and their overstimulation in pathological conditions, such as hyperhomocysteinemia, is related to a range of cardiovascular disorders. On the other hand we demonstrated that blockade of NMDA receptors depresses heart function. There is a need for the intensive study of NMDA receptor in cardiovascular system as potential theraputical target both in prevention and treatment of cardiovascular disorders.
\end{abstract}

Keywords: NMDA receptors, glutamate receptors, cardiovascular system, homocysteine

\section{SAŽETAK}

$N$-metil-D-aspartatni (NMDA) receptori pripadaju porodici glutamatnih jonotropnih receptora, zajedno sa AMPA ( $\alpha$-amino-3-hidroksi-5-metil-4-izoksazolpropionska kiselina), kainatnim $i \delta$-receptorima. Svi navedeni receptori su transmembranski proteini sastavljeni od četiri subjedinice. NMDA receptori imaju nekoliko jedinstvenih osobina u odnosu na ostale jonotropne glutamatne receptore: neophodnost istovremenog vezivanja dva koagonista, glutamata $i$ glicina, za aktivaciju receptora; dvojna kontrola aktivacije receptora, ligand-zavisna (vezivanje glutamata i glicina) $i$ voltaž-zavisna (blokada jonom magnezijuma); i ulazak znatne količine jona kalcijuma nakon aktivacije receptora. Sve više istraživanja se bavi fiziološkim $i$ patofiziološkim ulogama NMDA receptora van nervnih tkiva, pre svega u kardiovaskularnom sistemu. NMDA receptori postoje u svim tipovima ćelija koje se nalaze u kardiovaskularnom sistemu, $i$ njihova prekomerna stimulacija u patološkim stanjima, kao što je hiperhomocisteinemija, se dovodi u vezu sa velikim brojem poremećaja kardiovaskularnog sistema. Sa druge strane mi smo ukazali na činjenicu da blokada NMDA receptora izaziva slabljenje srčane funkcije. Nameće se potreba za svobuhvatnim istraživanjem NMDA receptora u kardiovaskularnom sistemu kao mogućeg terapijskog oruđa, kako u prevenciji, tako i u lečenju poremećaja kardiovaskularnog sistema.

Ključne reči: $N M D A$ receptori, glutamatni receptori, kardiovaskularni sistem, homocistein

\begin{aligned} & \multicolumn{2}{c}{ ABBREVIATIONS } \\ & ATD - amino-terminal domain Hcy TL - homocysteine thiolactone \\ & AMPA - $\alpha$-amino-3-hydroxy-5-methyl-4-isoxazolepropionic acid Hhcy - hyperhomocysteinemia \\ & CBS - cystathione $\beta$-synthase LBD - ligand-binding domain \\ & CNS - central nervous system MMP - matrix metalloproteinase \\ & CVS - cardiovascular system NMDA - N-methyl-D-aspartate \\ & CTD - carboxyl-terminal domain NO - nitric oxide \\ & DNA - deoxyribonucleic acid RNA - ribonucleic acid \\ & EAAT - Excitatory Amino Acid Transporters ROS - reactive oxygen species \\ & eNOS - endothelial nitric oxide synthase TMD - transmembrane domain \\ & Hcy - homocysteine VSMC - vascular smooth muscle cells \end{aligned}




\section{INTRODUCTION}

N-methyl-D-aspartate (NMDA) receptors belong to ionotropic glutamate receptor family, together with $\alpha$-amino-3-hydroxy-5-methyl-4-isoxazolepropionic acid (AMPA) receptors, kainite receptors and $\delta$-receptors. All of these receptors are integral membrane proteins, composed of four subunits configured so as to form transmembrane ion channel. Each of these subunits contain four domains: two extracellular domains, 1) the amino-terminal domain (ATD) and 2) the ligand-binding domain (LBD), 3) the transmembrane domain (TMD), and an 4) intracellular carboxyl-terminal domain (CTD). There are several types of subunits that can form the ionotropic glutamate receptor, but each glutamate receptor is made only by subunits within the same receptor group (1). NMDA receptors are made of three types of subunits, usually denoted as GluN1, GluN2 and GluN3. GluN1 and GluN3 subunits bind glycine, and GluN2 subunits bind glutamate. From the fact that NMDA receptors are composed form two obligatory glycine binding GluN1 subunits and two glutamate binding GluN2 subunits (or one GluN2 subunit and one glycine binding GluN3 subunit) derives their unique feature among other glutamate receptors - requirement of both coagonists, glutamate and glycine, for activation (2). Another peculiarity of NMDA receptors is related to magnesium $\left(\mathrm{Mg}^{2+}\right)$ blockade of ion channel of NMDA receptors. Namely, during resting membrane potential most of subtypes of NMDA receptors are blocked by $\mathrm{Mg}^{2+}$ from extracelular space, which greatly hinders the flow of ions through the channel. Due to depolarization of cell membrane, voltage-dependent $\mathrm{Mg}^{2+}$ block is removed, allowing the flow of ions through the pore of NMDA receptors. The resulting entry of $\mathrm{Ca}^{2+}$ initiates a series of intracellular signaling cascades, which alter the functioning of the cells by activation of different kinases and phosphatases (3).

Beside the known facts about the significance and function of NMDA receptors in central nervous system (CNS), as well as the relationship between dysfunction of NMDA receptors and certain diseases of nervous system (Alzheimer disease), the research data in past years indicated the presence of NMDA receptors in many other organs and tissues (4-7). Regarding the cardiovascular system (CVS), the NMDA receptors were first discovered in a rat cardiomyocytes (8). The NMDA receptors are also found in endothelial cells and vascular smooth muscle cells (VSMC) $(9,10)$. Bearing in mind the pathophysiological significance of effects of homocysteine (Hcy) in developing of atherosclerosis and consequent disorders, in the limelight comes the possibility that Hcy exerts its negative effects through NMDA receptors (11).

Concerning the crucial role of $\mathrm{Ca}^{2+}$ in heart function, as well as in function of vascular smooth muscle cells and endothelial cells, the NMDA receptors could have great importance in maintaining of homeostasis in CVS. In that sense, this review addresses on the recent insights in functions of NMDA receptors in CVS, as well as possibility of
Table 1. The names of NMDA receptor subunits in accordance with the NC-IUPHAR nomenclature

\begin{tabular}{cccc}
\hline & $\begin{array}{c}\text { NC-IUPHAR } \\
\text { name of subunit }\end{array}$ & $\begin{array}{c}\text { Name of human } \\
\text { gene }\end{array}$ & $\begin{array}{c}\text { Location on } \\
\text { the human } \\
\text { chromosomes }\end{array}$ \\
\cline { 2 - 3 } NluN1 & GluN2A & GRIN2A & 9q34.3 \\
GluN2B & GRIN2B & $16 \mathrm{p} 13.2$ \\
GluN2C & GRIN2C & 12 \\
GluN2D & GRIN2D & $19 \mathrm{q} 13.1$ \\
GluN3A & GRIN3A & $9 \mathrm{q} 31.1$ \\
\hline
\end{tabular}

NC-IUPHAR - International Union of Pharmacology Committee on Receptor Nomenclature and Drug Classification

targeting of NMDA receptors as potential therapeutic option in various cardiovascular disorders.

\section{STRUCTURE OF NMDA RECEPTORS}

As already mentioned above, NMDA receptors are composed of three different types of subunits, GluN1, GluN2 and GluN3 (Figure 1A). GluN1 subunit is encoded by single gene, but due to posttranslational processing of RNA arise eight different splice variants, while GluN2 subunit is encoded by four (A - D), and GluN3 (A and B) subunit by two different genes (Table 1) (12-14). By combining of different GluN1 and GluN2 subunits are formed NMDA receptors with different functional characteristics. Different splice variants of GluN1 subunit determine characteristics of NMDA receptors such as modulation by zinc, polyamines, and a protein kinase $\mathrm{C}$, as well as binding to the intracellular proteins (calmodulin, calmodulindependent protein kinase II, $\alpha$-actinin-2) $(15,16)$. Type of GluN2 subunit determines the biophysical properties of a channel such as the conductivity of a channel, the average time of opening, sensitivity to voltage-dependent $\mathrm{Mg}^{2+}$ block $(16,17)$. If, in addition to GluN1 and GluN2 subunits NMDA receptor contains GluN3A subunit also, it causes a decrease in the conductivity and permeability channels for $\mathrm{Ca}^{2+}$, which was confirmed by registering the ionic currents resulting from activation of the NMDA receptor in neurons in which these receptors do not include subunit GluN3A (18).

Three models have been proposed for the conclusion of NMDA receptors. According to the first model, subunits form stable homodimers, GluN1-GluN1 and GluN2-GluN2, which can then connect and form a tetrameric receptor (19). Tetrameric receptor structure, on the basis of the second proposed model, is created by adding of two GluN2 monomers to GluN1-GluN1 homodimer (20). In accordance with the third model, initially are created GluN1-GluN2 heterodimers, which then tetramerize (21) (Figure 1B). 
A Ions entering the cell through a pore of the NMDA receptor $\Delta \Delta$
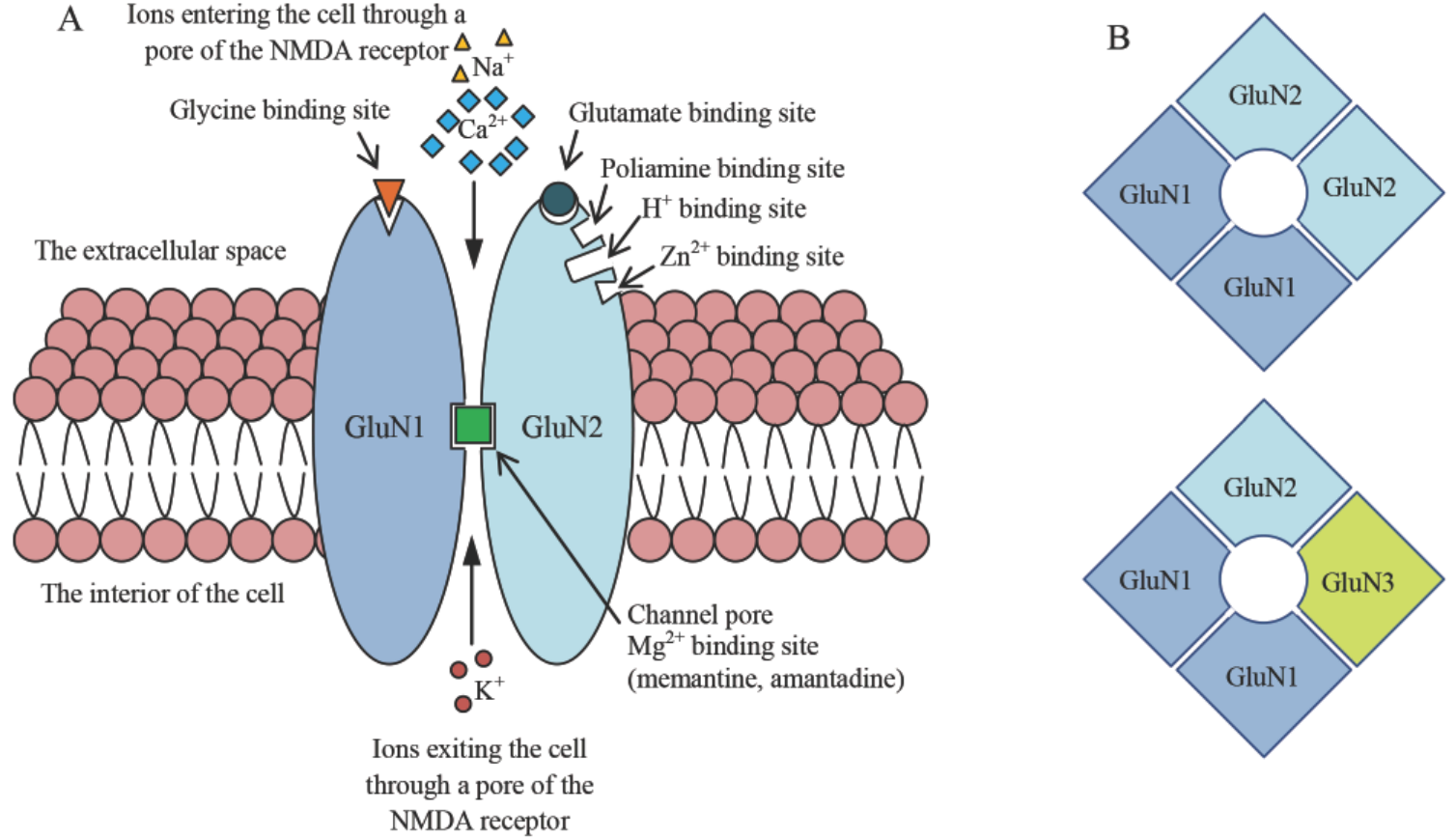

NMDA receptor

Figure 1. Schematic representation of NMDA receptor (A) and spatial arrangement of subunits that constitute the NMDA receptor (B)

Like other ionothorpic glutamate receptor subunits, all subunits of NMDA receptors are composed of four domains: amino-terminal domain (ATD), ligand-binding domain (LBD), transmembrane domain (TMD) and carboxy-terminal domain (CTD) (Figure 2). The extracellular ligand-binding domain (LBD) form two extracellular string of amino acids, which are labeled as S1 and S2 (22). All LBD are clamshell-shaped, wherein the polypeptide seg- ment S1, which is connected to the M1 helix of a transmembrane domain, forms a major part of one side of the „clamshell” (D1), while the polypeptide segment S2, which is located between M3 and M4 helices of transmembrane domain, forms a major part of the other side of the "shell" (D2). In this way it is formed a pocked or gap in which is located the agonist binding site. The matching agonists, glutamate, and glycine in the case of NMDA receptors,

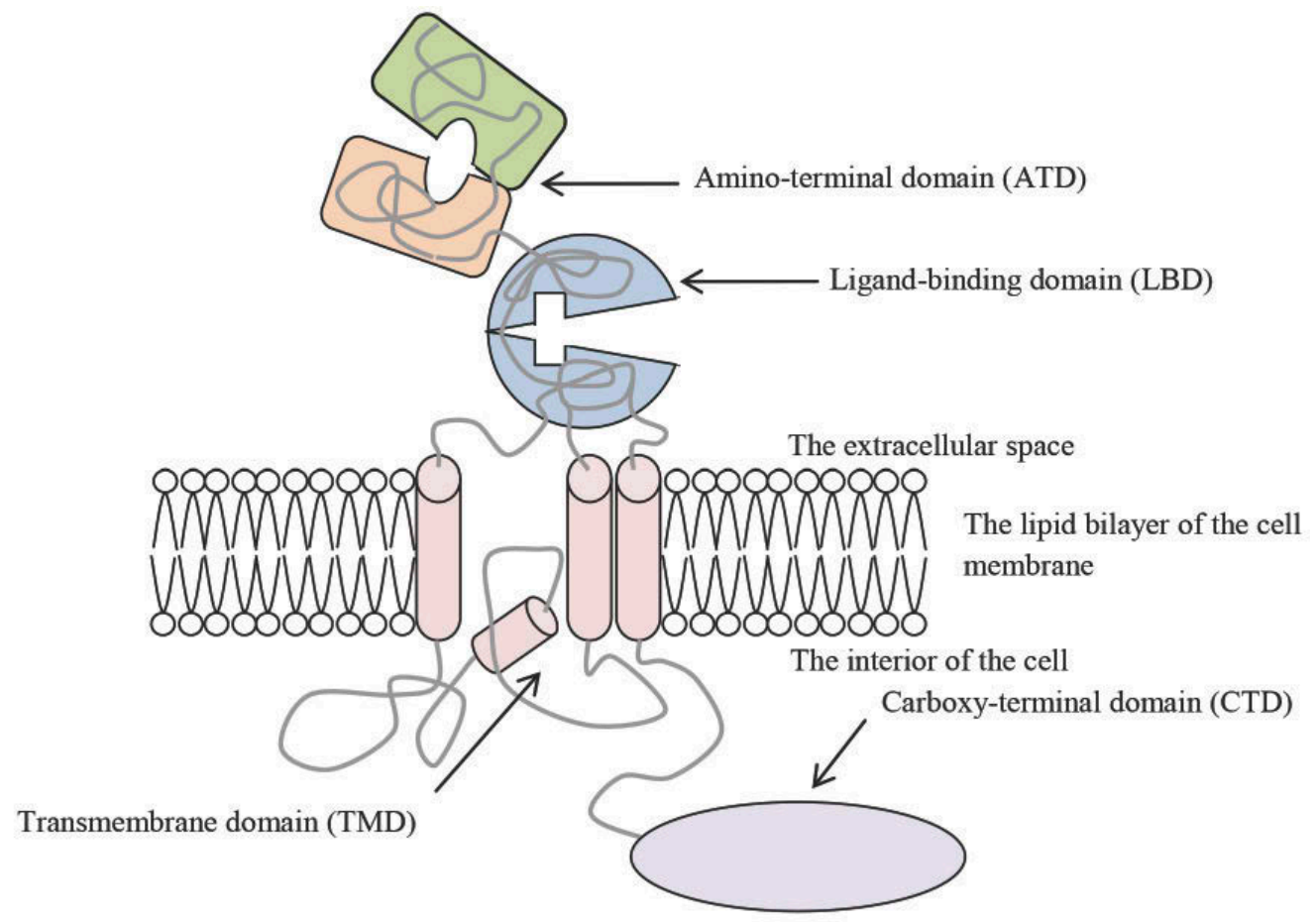

Figure 2. Schematic representation of structure of NMDA receptor subunits 
contain groups that bind to the $\alpha$-amino and $\alpha$-carboxyl group of LBD. Parts of LBD that form atomic bonds with ligands are highly similar in all glutamate receptors and built mainly by the amino acid residues that belong to the D1 section of LBD. Agonist binding to a LBD causes a conformational change, and it was found that binding of agonist leads to convergence of D1 and D2 and taking more closed conformation form, while in the free form D1 and D2 are separated and take up a more open conformation.

The extracellular amino-terminal domain (ATD) is made up of approximately 350 amino acid residues and, similarly to LBD, forms a clamshell-like structure which reacts with a number of allosteric modulators and thus affects the activity of NMDA receptor. ATD has a role in the regulation of receptor function, and it is not essential for connection of the subunits and construction of the NMDA receptor. It has been proven that ATD of GluN2 subunit control pharmacological and kinetic properties of NMDA receptor, such as: agonist binding activity, deactivation time, the opening probability, the median duration of opening and closing (23). ATD consists of two parts, the R1 and R2, which form a cleft inside which are located more binding sites: 1) a hydrophilic binding site built up of polar amino acid residues that form the binding site for $\mathrm{Zn}^{2+}$, located near the outer aperture of the cleft; 2) a hydrophobic binding site for ifenprodil, located deep in the cleft; and 3) binding place for $\mathrm{Na}^{+}$and $\mathrm{Cl}^{-}$ions, whose role is not fully elucidated (24).

Transmembrane domain (TMD) of all glutamate receptors is linked to LB) by three short links. TMD contains three transmembrane helices, which are marked as M1, M3 and M4, and a membrane re-entrant loop, marked as M2 (25). The transmembrane helices, M1, M3 and M4, each of the four subunits of the receptor form a transmembrane channel; M2 loops limit the inner edge, while parts of the M3 helix limit the outer edge of the channel pore. Parts of M3 helices extending at each other, probably forming a gate that prevents the flow of ions when the receptor is inactive. M1 and M3 helices form the core of the channel, and M4 helix of one subunit makes the connection with the M1 and M3 helices of other subunits. Next to that, linking region preceding M1 (pre-M1) forms a short helix that is parallel to the plane of the membrane and creates links to the carboxyl- and amino-terminal ends of the M3 and M4 helices $(25,26)$. Pre-M1 helices of all four subunits crate a cuff around the outer channel pore aperture, which may have a significant impact on channel controlling.

The carboxy-terminal domain (CTD) exhibits the highest degree of diversity among all glutamate receptors. It is believed that the CTD affect the stabilization of the receptor, posttranslational modification and labeling of the receptor for breakdown. Deleting the CTD in GluN1 and GluN2A subunits does not affect the function of NMDA receptors, but influences the controlling of the NMDA receptor, because CTD contains a phosphorylation sites and binding sites for intracellular proteins involved in the regulation of its functions (27). Several subunits of NMDA receptors via
CTD are associated with $\mathrm{Ca}^{2+} /$ calmodulin-dependent protein kinase II, enabling the further expansion of the local signal, thereby allowing the spatial and temporal specificity of receptor regulation. Recent studies suggest the possibility of transmitting the signals through NMDA receptors based on the relationship between CTD and related protein kinases, independently of $\mathrm{Ca}^{2+}$ influx (28).

\section{MODULATION OF NMDA RECEPTOR ACTIVITY}

NMDA receptors are unique in the group of glutamate receptors since it is required simultaneous binding of glycine for GluN1 (or GluN3) subunits and glutamate for GluN2 subunits for receptor activation (29). In certain sources of literature glycine is mentioned as a modulator of NMDA receptors, in order to distinguish it from the Lglutamate, which is a specific agonist of the entire receptor group. However, since their binding sites are structurally similar, they likely have the equal role in the activation of NMDA receptor. Even though, in physiological conditions, the glycine and glutamate still have different roles in the activation of NMDA receptors. While the L-glutamate is released from the nerve endings in the synaptic cleft and represents an "active" neurotransmitter, is believed that a small amounts of glycine, which normally exists in the synaptic cleft, is sufficient for receptor activation (30).

Within the glycine binding site the $\alpha$-carboxyl group of glycine forms a hydrogen bond with the amino acid arginine at position 522 (Arg522), the threonine at position 518 (Thr518) and serine at position 688 (Ser688). The amino group of glycine reacts with the carbonyl group of proline at position 516 (Pro516), hydroxyl group of threonine at position 518 (Thr518) and the oxygen of the carboxyl group of aspartic acid at position 732 (Asp732) $(1,31)$.

Besides the glycine, for glycine binding site also can bind $\mathrm{D}$ and $\mathrm{L}$-isomers of serine and alanine, and to act as agonists of the GluN1 subunit (32). D-serine is significantly more potent in comparison to L-serine, and probably represents the primary ligand for GluN1 subunit in particular regions of the brain, such as supraoptic nuclei (33).

Glutamate binds to GluN2 subunits. $\alpha$-carboxylate group of glutamate reacts with arginine at position 518 (Arg518), and the $\gamma$-carboxyl group of glutamate binds to the tyrosine at position 730 (Tyr730), whereby between the domains is formed hydrogen bonds between the tyrosine at position 730 (Tyr730) and the glutamic acid at position 413 (Glu413) (34). In the endogenous agonists of GluN2 subunit, next to glutamate, also include D and L-aspartate, homocysteine and cysteine sulphate (35-37).

There are many competitive antagonists of NMDA receptor that are specific for GluN1 subunit, such as 7-chlorokynurenic acid and its analog - 5,7-dichlorokynurenic acid (5,7-DCKA) (29). Furthermore, the anesthetic effects of xenon are independent of the action of the GABA-ergic nerve transmission, but are dependent on the inhibition of the NMDA receptor (38). 
The competitive antagonists of NMDA receptor specific for GluN2 subunit such as (R)-2-amino-5-phosphonopentanoate, are used in order to distinguish the effects of NMDA recepotrs and other ionotropic glutamate receptors (primarily AMRA receptors) (39). Great difficulty arises from the inability to synthesize compounds that would selectively inhibit certain subtypes of GluN2 subunit $(A-D)$, which is consequence of high degree of homology between the LBD of GluN2 subunits.

Noncompetitive antagonists block NMDA receptors while they are closed. In this group of antagonists are classified ethanol and dynorphins, whereby ethanol inhibits GluN2B subunit containing NMDA receptors, and dynorphins inhibit GluN2A subunit containing NMDA receptors (40). Unlike to noncompetitive antagonists, for action of uncompetitive antagonists it is essential that NMDA receptor channel is open, in order to reach their binding site. This group of NMDA receptor antagonist includes memantine and MK-801 (dizocilpine).

Allosteric modulators of glutamate receptors attract great attention lately because of the possibility of fine impact on the physiological functioning of the receptor, as well as the possibility to use for therapeutic purposes. The positive and negative allosteric modulators have a number of therapeutic advantages in comparison with agonists and antagonists of glutamate receptors, including greater selectivity for individual subunits that are part of the receptor. It is believed that better tolerance of allosteric modulators in clinical practice is consequence of their actions on the existing level and the form of the receptor activity, in contrast to the agonists and antagonists that induce or complete blockade or excessive stimulation.

\section{NMDA RECEPTORS AND CARDIOVASCULAR SYSTEM}

As already mentioned NMDA receptors play a key role in the functioning of the central nervous system (CNS), but a few decades ago some authors have pointed to the possibility of their existence outside of nerve tissues. Results of the experiments based on the cloning of complementary DNA of humane GluN2C subunit, showed $88 \%$ of similarity to rat GluN2C subunit, as well as the great representation of this subunit, as in some parts of the nervous tissue, but also in other tissues, especially in heart (41). The researching of the time and spatial tissue distribution of radiolabelled NMDA receptor antagonists ([3H]CGS and [3H] MK-801) showed widespread distribution of these receptors in a number of organs, such as heart, lung, kidney and stomach (42). Based on the results of their research Leung and coauthors suggested the possible existence of homooligomeric NMDA receptors composed of GluN1 subunits in the rat heart (43). Namely, these authors did not find the GluN2 subunit, but only the GluN1. On the other hand, researching the developmental distribution of NMDA receptors subunits, Seeber and colleagues showed presence of GluN2B subunit in rat heart, which was de- tected in the cardiac tissue of the early development stages until the tenth week of postnatal life (44). Furthermore, these authors did not find the existence of GluN1 subunits at any stage of development. The results of these studies are inconsistent and in some of its parts are contradictory.

It is also confirmed the existence of NMDA receptors in the endothelium of blood vessels in different parts of the body. The application of glutamate and D-serine (which binds to the glycine binding site) causes the activation of NMDA receptors, which activate endothelial nitric oxide synthase (eNOS) causing increased production of nitric oxide (NO) and vasodilatation in brain arteries. In this cascade mediate astrocytes that store glutamate and D-serine and release them depending on the neural activity $(45,46)$. Studying the adverse effects of homocysteine (Hcy) on CVS, as well as potential mechanisms by which these effects are achieved, Chen and coworkers indicated the existence of GluN1 and GluN2A subunits in the rat carotid arteries, and the expression of NMDA receptor subunits in rat aortic endothelium (47). Within the same research it was shown that Hcy induces an increase in the expression of GluN1 subunit and increase in cell proliferation, while the previous administration of MK801 precluded above mentioned effects of Hcy.

Glutamate concentration in cerebrospinal fluid of rats is about $11.4 \mathrm{mmol} / \mathrm{L}$, while the plasma concentrations are significantly higher $(48,49)$. Based on the aforementioned fact, it can be concluded that peripheral NMDA receptors are under tonic, constant activation. However, the application of activators of these receptors in peripheral tissues increases their activity (50-52). One of possible explanations could be that the interstitial concentration of glutamate is not the same as the plasma concentration. In the CNS the glutamate concentration is maintained within a narrow range due to activity of specific glutamate transporter, EAAT (Excitatory Amino Acid Transporters), which remove glutamate from the synaptic cleft, thereby preventing overstimulation of neurons and the consequent neurotoxicity (53). Since the different isoforms of these transporters are discovered in peripheral tissues inter alia, in the CVS, there is a possibility that the concentration of glutamate in the intercellular space of these tissues is regulated by EAAT $(54,55)$. Further explanation provides the possibility of lower sensitivity of NMDA receptors in the periphery, or a lower affinity for glutamate and glycine compared to NMDA receptors in the CNS. In that sense, Laketić-Ljubojević and colleagues pointed out the much higher value of dissociation constant $\left(K_{d}\right)$ for glutamate that binds to NMDA receptors on osteoblasts compared to NMDA receptors in the nervous tissue (56).

There is increasing information concerning the importance of NMDA receptors in regulation of the electrical activity of the heart (7). Also, the increasing number of studies are focused on the impact of overstimulation of these receptors in the heart and CVS, where chronic activation of these receptors by agonists cause considerable electrophysiological disorders and increases the probability of ventricular arrhythmias (57). 
D'Amico and coauthors showed that inhibition of NMDA receptors during reperfusion decreases risk of arrhythmia occurrence, as well as $\mathrm{Ca}^{2+}$ accumulation in mitochondria (58). Similar conclusions were performed by Sun and coworkers based on results of their research (59). Namely, preconditioning with MK-801 and gabapentin (a glutamate release inhibitor), before myocardial infarction induced in vivo by ligation of the left anterior descending coronary artery for 30 minutes, significantly mitigated ventricular arrhythmias, improved SERCA2a expression and activity of $\mathrm{Ca}^{2+}$-ATPase in sarcoplasmic reticulum, and consequently reduced $\mathrm{Ca}^{2+}$ accumulated in mitochondria. On the other hand preconditioning with dihydrokainate (a glutamate transporter inhibitor) had quite the opposite effect. Furthermore, in this study it was shown that myocardial infarction induces increase in serum glutamate concentration. The ensuing conclusion from the results of this study is that glutamate certainly has a role in the pathogenesis of reperfusion induced arrhythmias, and probable mechanism may be associated with $\mathrm{Ca}^{2+}$ overload via the NMDA receptor. Hereupon, reperfusion arrhythmias could be prevented by applying the glutamate release inhibitors or NMDA receptor antagonists.

Increase in $\mathrm{Ca}^{2+}$ concentration due to NMDA receptor activation causes imbalance in production and elimination of free radicals and oxidative stress. These effects induced by overstimulation of NMDA receptors could be diminished by MK-801, or by scavengers of reactive oxygen species (ROS) such as glutathione and N-acetylcystein, as it is demonstrated in the study by Gao and coauthors (60). Next to that activation of NMDA receptors in cultured neonatal rat cardiomyocytes, in the context of the results of this research, also increased levels of cytosolic cytochrome c and $17-\mathrm{kDa}$ caspase-3, and depolarized mitochondrial membrane potential, leading to cardiomyocyte apoptosis. These findings suggest that overstimulation of NMDA receptors in the cardiomyocytes could induce apoptosis via a $\mathrm{Ca}^{2+}, \mathrm{ROS}$, and caspase-3 mediated pathway, and also point out the importance of NMDA receptors in pathogenesis of myocardial disorders. Furthermore, deletion of GluN1 subunit in cardiomyocytes led to reduced production of ROS induced by Hcy, as well as decreased concentration of NO and matrix metalloproteinase 9 (MMP9) in mitochondria of the heart $(61,62)$. Meneghini and coauthors also have pointed out to protective effects of the blockade of the NMDA receptors by memantine (63). Memantine prevented the nuclear size reduction in cardiomyocytes in rats exposed to cold stress.

Results of experiments conducted by our research group also indicated the role of NMDA receptors in regulation of heart function. Application of glutamate or glicine did not induce any change in heart function, coronary flow or oxidative stress in retrogradely perfused rat hearts according to Langendorff technique, while on the other hand their combined use caused decrease in observed cardiodynamic parameters, coronary flow and increase in oxidative stress biomarkers (64). In the case of the combined use of glutamate and/or glycine with verapamil (blocker of L type $\mathrm{Ca}^{2+}$ channels) in the same experimental model, the slightest changes were observed in the group where verapamil was administered along with glutamate and glycine, which suggests that the activation of the NMDA receptors allows the influx of certain amounts of $\mathrm{Ca}^{2+}$, insufficient to nullifies the effects of verapamil, but sufficient enough to significantly increase observed cardiodynamic parameters compared to other experimental groups in this study (65).

All mentioned facts indicate the importance of NMDA receptors in the regulation of physiological activities, as well as the mechanisms of pathological processes, in the CVS.

\section{NMDA RECEPTORS AND HOMOCYSTEINE IN CARDIOVASCULAR SYSTEM}

Homocysteine (Hcy) is non-protein amino acid which occurs as an intermediate product during the metabolism of amino acids methionine and cysteine. In methionine cycle Hcy represents the product in the metabolism of methionine, but also represents a substrate for the synthesis of this amino acid (Figure 3).

On the significance of Hcy in the pathophysiology of atherosclerosis and consequent disorders of the CVS first noted Kilmer McCully almost half a century ago. Namely, Kilmer McCully described a case of advanced atherosclerosis in the medium and small arteries of large number of organs and tissues in child with high concentrations of homocysteine, cystathionine and homocysteine disulfide in the plasma and urine, and also low concentrations of methionine (66). This case report became the basis for homocysteine theory of atherosclerosis, and since then, many researchers deal with the effects of Hcy on the CVS, as well as the molecular mechanisms that mediate in these adverse effects of Hcy.

The significance of the methionine is reflected in large number transmethylation reactions, in which the methyl group of methionine is transferred to other molecules (DNA, RNA, proteins, lipids), as well as in the synthesis of other sulfur-containing compounds (cystathionine, taurine). In a methionine cycle occurs Hcy (Figure 3), which can serve as a substrate for the enzyme methionine synthase in the remethylation pathway, which takes place in the in case of methionine deficiency. This metabolic pathway requires the vitamin $B_{12}$, which acts as cofactor for enzyme methionine synthase, as well as folate (vitamin $B_{q}$ ), which donates a methyl group to Hcy during remethylation. Otherwise, Hcy enters into the series of reactions which together form a transsulfuration metabolic pathway, where the key role has enzyme cystathione $\beta$-synthase (CBS), for whose activity is essential vitamin $B_{6}(67,68)$. Any disruption of described metabolic cascade causes the accumulation of Hcy in the cells which is consequently converted to a considerably more toxic form, homocysteine thiolactone (Hcy TL), by action of the enzyme methi- 


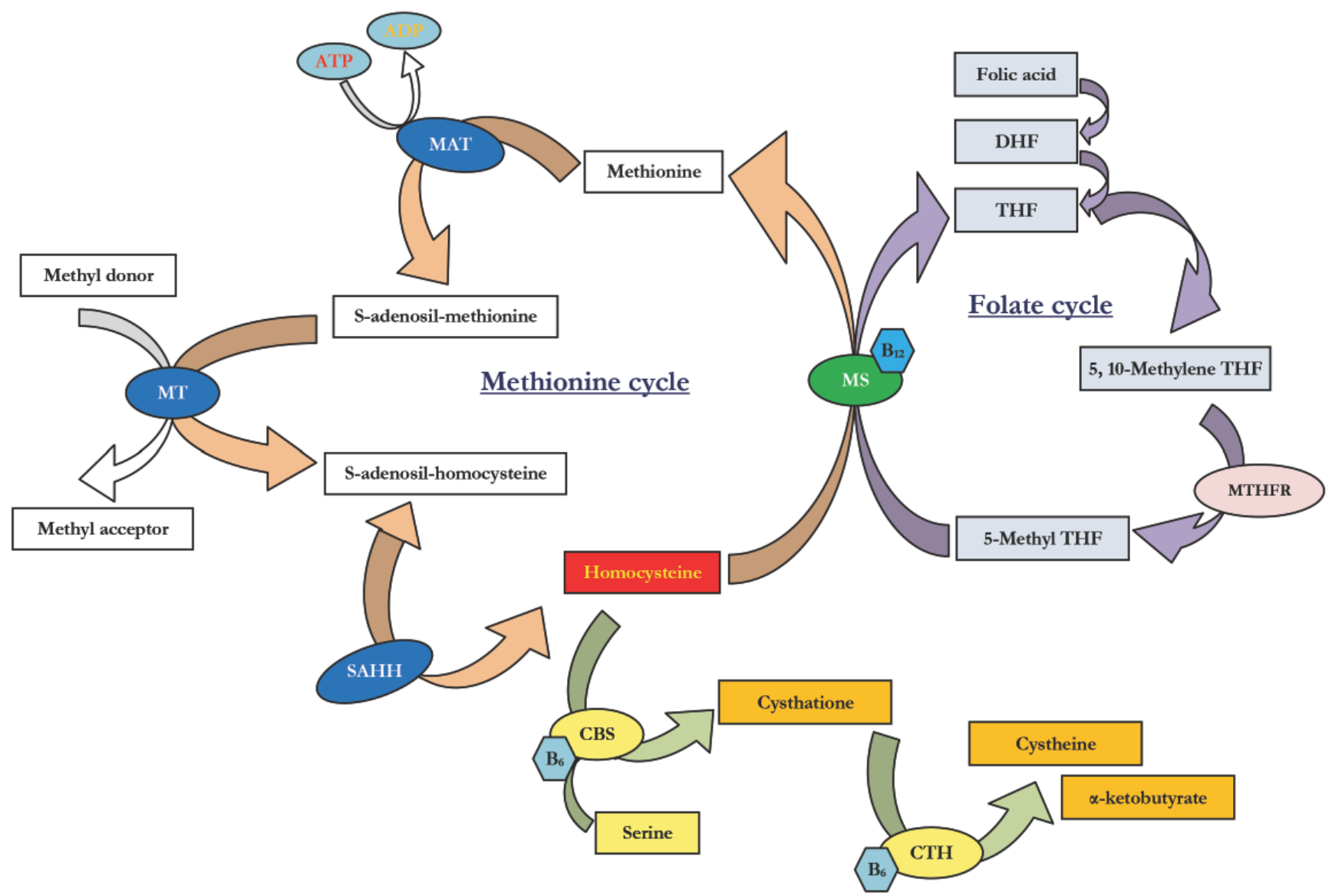

Figure 3. Methionine cycle

MAT, methionine adenosyltransferase; MT, methyltransferase; SAHH, S-adenosylhomocysteine hydrolase; MS, methionine synthase; DHF, dihydrofolate; THF, tetrahydrofolate; MTHFR, 5,10-methylenetetrahydrofolate reductase; CBS, cystathione $\beta$-synthetase; CTH, $\gamma$-cystathionase.

onyl-tRNA synthetase. Hcy TL reacts readily with amino groups of the large number of proteins, causing homocysteinylation of the protein, which dramatically change the protein activity (69).

Hyperhomocysteinemia is a condition characterized by an increase in the plasma value of total homocysteine concentration above $15 \mu \mathrm{mol} / \mathrm{L}$. Depending on the value of plasma Hcy, HHcy is classified as moderate $(16-30 \mu \mathrm{mol} / \mathrm{L})$, intermediate (31-100 $\mu \mathrm{mol} / \mathrm{L})$ and severe (higher than 100 $\mu \mathrm{mol} / \mathrm{L})$. The causes of HHcy may be classified into four major categories: 1) genetic disorders of enzymes involved in homocysteine metabolism, 2) inadequate intake of folate, vitamin $\mathrm{B}_{12}$ and $\mathrm{B}_{6}, 3$ ) increased intake of methionine, and 4) reduction in kidney function (Figure 4), (70). HHcy can also be induced iatrogenically.

HHcy induces interstitial myocardial fibrosis, resulting in developing systolic and diastolic heart dysfunction and chronic heart failure (71). Presumed mechanism of mentioned pathological changes involves the activation of NMDA receptors by Hcy, and this assumption is based on the fact that NMDA receptor blockers reduce the oxidative stress caused by Hcy. As a consequence of stimulation of NMDA receptors in the cardiomyocytes matrix metalloproteinases (MMP - zinc-containing endopeptidases) are activated, and these enzymes change the composition of extracellular matrix in the myocardium. The activation of MMP due to HHsy reduces elastin/collagen ratio, increases collagen deposition in interstitial tissue (fibrosis) between endothelial cells and myocytes, which has the proarrhythmogenic effect, while the use of an NMDA receptor antagonists prevents the activation of MMPs $(62,72)$.

HHcy induces a cascade of reactions which cause endothelial dysfunction and increased accumulation of ex-

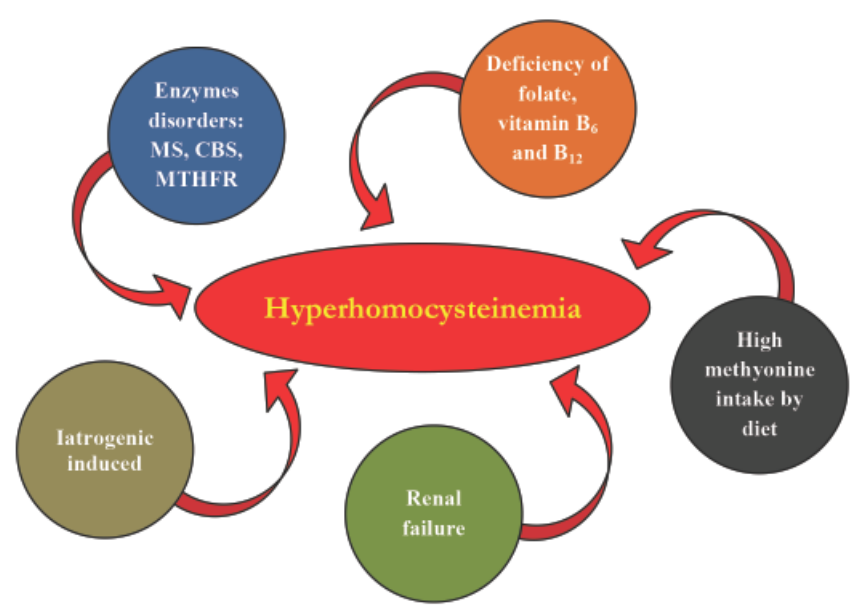

Figure 4. Possible causes of hyperhomocysteinemia 
tracellular matrix, and the mechanisms that mediate these disorders include increased production of reactive oxygen and nitrogen species (73-77).

Based on the results of our experimental group it can be concluded that both overstimulation and depression of NMDA receptor activity in heart decrease cardiac function (78). Namely, acute administration of Hcy TL, as well as MK-801, in isolated rat hearts decreased heart function and coronary flow, but the effects of these substances were the opposite in the case of co-administration.

\section{EXPERT OPINION}

It is definitely clear, not only that NMDA receptors exist in the CVS, but also to play an important role in the regulation of a physiological process, as well as in pathogenesis of cardiovascular disorders. Bearing in mind the medical and social importance of disorders of CVS in which NMDA receptors could mediate, there is a need for their studying as a potential therapeutic target. NMDA receptors exhibit a considerable complexity regarding the diversity of subunits that compose them and which greatly affect the properties of the receptor, as well as necessity for extremely precise regulation of their action. Namely, it has been shown that blockade of NMDA receptors protect the heart from reperfusion injury (59), but our results showed that blockade of NMDA receptors have adverse effects on heart function (78). It is necessary to focus attention on the synthesis of pharmaceuticals that can specifically act on the peripheral NMDA receptors, and which are capable to finely correct NMDA receptor activity.

\section{ACKNOWLEDGMENTS}

This project was supported by Grant no. 175043 from the Ministry of Science and Technical Development of the Republic of Serbia, and the Junior Project 04/2011, Faculty of Medical Sciences, University of Kragujevac, Serbia.

\section{CONFLICT OF INTERESTS}

None of the authors of the present study has any actual or potential conflicts of interest to disclose, including financial, personal, or other relationships with specific persons or organisations.

\section{REFERENCES}

1. Traynelis SF, Wollmuth LP, McBain CJ, Menniti FS, Vance KM, Ogden KK, Hansen KB, Yuan H, Myers SJ, Dingledine R. (2010). Glutamate receptor ion channels: structure, regulation, and function. Pharmacol Rev, 62(3), 405-96.
2. Sobolevsky AI. (2015). Structure and gating of tetrameric glutamate receptors. J Physiol, 593(1), 29-38.

3. Dravid SM, Erreger K, Yuan H, Nicholson K, Le P, Lyuboslavsky P, Almonte A, Murray E, Mosely C, Barber J, French A, Balster R, Murray TF, Traynelis SF. (2007). Subunit-specific mechanisms and proton sensitivity of NMDA receptor channel block. J Physiol, 581(Pt 1), 107-28.

4. Morris RG, Anderson E, Lynch GS, Baudry M. (1986). Selective impairment of learning and blockade of longterm potentiation by an N-methyl-D-aspartate receptor antagonist, AP5. Nature, 319(6056), 774-6.

5. Martin SJ, Grimwood PD, Morris RG. (2000). Synaptic plasticity and memory: an evaluation of the hypothesis. Annu Rev Neurosci, 23, 649-711.

6. Snyder EM, Nong Y, Almeida CG, Paul S, Moran T, Choi EY, Nairn AC, Salter MW, Lombroso PJ, Gouras GK, Greengard P. (2005). Regulation of NMDA receptor trafficking by amyloid-beta. Nat Neurosci, 8(8), 1051-8.

7. Bozic M, Valdivielso JM. (2015). The potential of targeting NMDA receptors outside the CNS. Expert Opin Ther Targets, 19(3), 399-413.

8. Morhenn VB, Waleh NS, Mansbridge JN, Unson D, Zolotorev A, Cline P, Toll L. (1994). Evidence for an NMDA receptor subunit in human keratinocytes and rat cardiocytes. Eur J Pharmacol, 268(3), 409-14.

9. Betzen C, White R, Zehendner CM, Pietrowski E, Bender B, Luhmann HJ, Kuhlmann CR. (2009). Oxidative stress upregulates the NMDA receptor on cerebrovascular endothelium. Free Radic Biol Med, 47(8), 1212-20.

10. Pang X, Liu J, Zhao J, Mao J, Zhang X, Feng L, Han C, Li M, Wang S, Wu D. (2014). Homocysteine induces the expression of C-reactive protein via NMDAr-ROSMAPK-NF- $\kappa B$ signal pathway in rat vascular smooth muscle cells. Atherosclerosis, 236(1), 73-81.

11. Chen H, Fitzgerald R, Brown AT, Qureshi I, Breckenridge J, Kazi R, Wang Y, Wu Y, Zhang X, Mukunyadzi P, Eidt J, Moursi MM. (2005). Identification of a homocysteine receptor in the peripheral endothelium and its role in proliferation. J Vasc Surg, 41(5), 853-60

12. Monyer H, Sprengel R, Schoepfer R, Herb A, Higuchi M, Lomeli H, Burnashev N, Sakmann B, Seeburg PH. (1992). Heteromeric NMDA receptors: molecular and functional distinction of subtypes. Science, 256(5060), 1217-21.

13. Moriyoshi K, Masu M, Ishii T, Shigemoto R, Mizuno N, Nakanishi S. (1991). Molecular cloning and characterization of the rat NMDA receptor. Nature, 354(6348), 31-7.

14. Vyklicky V, Korinek M, Smejkalova T, Balik A, Krausova B, Kaniakova M, Lichnerova K, Cerny J, Krusek J, Dittert I, Horak M, Vyklicky L. (2014). Structure, function, and pharmacology of NMDA receptor channels. Physiol Res, 63 Suppl 1, 191-203.

15. Lin JW, Wyszynski M, Madhavan R, Sealock R, Kim JU, Sheng M. (1998). Yotiao, a novel protein of neuromuscular junction and brain that interacts with specific splice variants of NMDA receptor subunit NR1. J Neurosci, 18(6), 2017-27. 
16. Perez-Otano I, Schulteis CT, Contractor A, Lipton SA, Trimmer JS, Sucher NJ, Heinemann SF. (2001). Assembly with the NR1 subunit is required for surface expression of NR3A-containing NMDA receptors. J Neurosci, 21(4), 1228-37.

17. Monyer H, Burnashev N, Laurie DJ, Sakmann B, Seeburg PH. (1994). Developmental and regional expression in the rat brain and functional properties of four NMDA receptors. Neuron, 12(3), 529-40.

18. Matsuda K, Fletcher M, Kamiya Y, Yuzaki M. (2003). Specific assembly with the NMDA receptor 3B subunit controls surface expression and calcium permeability of NMDA receptors. J Neurosci, 23(31), 10064-73.

19. Qiu S, Hua YL, Yang F, Chen YZ, Luo JH. (2005). Subunit assembly of N-methyl-d-aspartate receptors analyzed by fluorescence resonance energy transfer. J Biol Chem, 280(26), 24923-30.

20. Atlason PT, Garside ML, Meddows E, Whiting P, McIlhinney RA. (2007). N-Methyl-D-aspartate (NMDA) receptor subunit NR1 forms the substrate for oligomeric assembly of the NMDA receptor. J Biol Chem, 282(35), 25299-307.

21. Schüler T, Mesic I, Madry C, Bartholomäus I, Laube B. (2008). Formation of NR1/NR2 and NR1/NR3 heterodimers constitutes the initial step in N-methyl-D-aspartate receptor assembly. J Biol Chem, 283(1), 37-46.

22. Stern-Bach Y, Bettler B, Hartley M, Sheppard PO, O'Hara PJ, Heinemann SF. (1994). Agonist selectivity of glutamate receptors is specified by two domains structurally related to bacterial amino acid-binding proteins. Neuron, 13(6): 1345-57.

23. Yuan H, Hansen KB, Vance KM, Ogden KK, Traynelis SF. (2009). Control of NMDA receptor function by the NR2 subunit amino-terminal domain. J Neurosci, 29(39), 12045-58.

24. Karakas E, Simorowski N, Furukawa H. (2009). Structure of the zinc-bound amino-terminal domain of the NMDA receptor NR2B subunit. EMBO J, 28(24), 3910-20.

25. Sobolevsky AI, Rosconi MP, Gouaux E. (2009). X-ray structure, symmetry and mechanism of an AMPA-subtype glutamate receptor. Nature, 462(7274), 745-56.

26. Banke TG, Traynelis SF. (2003). Activation of NR1/ NR2B NMDA receptors. Nat Neurosci, 6(2), 144-52.

27. Vissel B, Krupp JJ, Heinemann SF, Westbrook GL. (2002). Intracellular domains of NR2 alter calcium-dependent inactivation of N-methyl-D-aspartate receptors. Mol Pharmacol, 61(3), 595-605.

28. Aow J, Dore K, Malinow R. (2015). Conformational signaling required for synaptic plasticity by the NMDA receptor complex. Proc Natl Acad Sci U S A, 112(47), 14711-6.

29. Kleckner NW, Dingledine R. (1988). Requirement for glycine in activation of NMDA-receptors expressed in Xenopus oocytes. Science, 241(4867), 835-7.

30. Blanke ML, VanDongen AMJ. (2009). Activation Mechanisms of the NMDA Receptor. In: Van Dongen AM, editor. Biology of the NMDA Receptor. Boca Raton (FL): CRC Press/Taylor \& Francis, Chapter 13.
31. Furukawa H, Gouaux E. (2003). Mechanisms of activation, inhibition and specificity: crystal structures of the NMDA receptor NR1 ligand-binding core. EMBO J, 22(12), 2873-85.

32. Kolodney G, Dumin E, Safory H, Rosenberg D, Mori H, Radzishevsky I, Wolosker H. (2016). Nuclear compartmentalization of serine racemase regulates $\mathrm{d}$-serine production. Implications for $\mathrm{N}$-methyl-D-aspartate (NMDA) receptor activation. J Biol Chem, 291(6), 2630.

33. Panatier A, Theodosis DT, Mothet JP, Touquet B, Pollegioni L, Poulain DA, Oliet SH. (2006). Glia-derived Dserine controls NMDA receptor activity and synaptic memory. Cell, 125(4), 775-84.

34. Furukawa H, Singh SK, Mancusso R, Gouaux E. (2005). Subunit arrangement and function in NMDA receptors. Nature, 438(7065), 185-92.

35. Zhang X, Nadler JV. (2009). Postsynaptic response to stimulation of the Schaffer collaterals with properties similar to those of synaptosomal aspartate release. Brain Res, 1295, 13-20.

36. Abushik PA, Niittykoski M, Giniatullina R, Shakirzyanova A, Bart G, Fayuk D, Sibarov DA, Antonov SM, Giniatullin R. (2014). The role of NMDA and mGluR5 receptors in calcium mobilization and neurotoxicity of homocysteine in trigeminal and cortical neurons and glial cells. J Neurochem, 129(2), 264-74.

37. Nahum-Levy R, Lipinski D, Shavit S, Benveniste M. (2001). Desensitization of NMDA receptor channels is modulated by glutamate agonists. Biophys J, 80(5), 2152-66.

38. de Sousa SL, Dickinson R, Lieb WR, Franks NP. (2000). Contrasting synaptic actions of the inhalational general anesthetics isoflurane and xenon. Anesthesiology, 92(4), 1055-66.

39. Lester RA, Clements JD, Westbrook GL, Jahr CE. (1990). Channel kinetics determine the time course of NMDA receptor-mediated synaptic currents. Nature, 346(6284), 565-7.

40. Kash TL, Matthews RT, Winder DG. (2008). Alcohol inhibits NR2B-containing NMDA receptors in the ventral bed nucleus of the stria terminalis. Neuropsychopharmacology, 33(6), 1379-90.

41. Lin YJ, Bovetto S, Carver JM, Giordano T. (1996). Cloning of the cDNA for the human NMDA receptor NR2C subunit and its expression in the central nervous system and periphery. Brain Res Mol Brain Res, 43(1-2), 57-64.

42. Näsström J, Böö E, Ståhlberg M, Berge OG. (1993). Tissue distribution of two NMDA receptor antagonists, [3H]CGS 19755 and [3H]MK-801, after intrathecal injection in mice. Pharmacol Biochem Behav, 44(1), 9-15.

43. Leung JC, Travis BR, Verlander JW, Sandhu SK, Yang SG, Zea AH, Weiner ID, Silverstein DM. (2002). Expression and developmental regulation of the NMDA receptor subunits in the kidney and cardiovascular system. Am J Physiol Regul Integr Comp Physiol, 283(4), 964-71.

44. Seeber S, Becker K, Rau T, Eschenhagen T, Becker CM, Herkert M. (2000). Transient expression of NMDA receptor subunit NR2B in the developing rat heart. J Neurochem, 75(6), 2472-7. 
45. LeMaistre JL, Sanders SA, Stobart MJ, Lu L, Knox JD, Anderson HD, Anderson CM. (2012). Coactivation of NMDA receptors by glutamate and D-serine induces dilation of isolated middle cerebral arteries. J Cereb Blood Flow Metab, 32(3), 537-47.

46. Mothet JP, Pollegioni L, Ouanounou G, Martineau M, Fossier P, Baux G. (2005). Glutamate receptor activation triggers a calcium-dependent and SNARE proteindependent release of the gliotransmitter D-serine. Proc Natl Acad Sci U S A, 102(15), 5606-11.

47. Chen H, Fitzgerald R, Brown AT, Qureshi I, Breckenridge J, Kazi R, Wang Y, Wu Y, Zhang X, Mukunyadzi P, Eidt J, Moursi MM. (2005). Identification of a homocysteine receptor in the peripheral endothelium and its role in proliferation. J Vasc Surg, 41(5), 853-60.

48. Akanuma S, Sakurai T, Tachikawa M, Kubo Y, Hosoya K. (2015). Transporter-mediated L-glutamate elimination from cerebrospinal fluid: possible involvement of excitatory amino acid transporters expressed in ependymal cells and choroid plexus epithelial cells. Fluids Barriers CNS, 12, 11.

49. Lerma J, Herranz AS, Herreras O, Abraira V, Martín del Río R. (1986). In vivo determination of extracellular concentration of amino acids in the rat hippocampus. A method based on brain dialysis and computerized analysis. Brain Res, 384(1), 145-55.

50. McGee MA, Abdel-Rahman AA. (2012). Enhanced vascular neuronal nitric-oxide synthase-derived nitricoxide production underlies the pressor response caused by peripheral $\mathrm{N}$-methyl-D-aspartate receptor activation in conscious rats. J Pharmacol Exp Ther, 342(2), 461-71.

51. Liu Y, Zhou L, Xu HF, Yan L, Ding F, Hao W, Cao JM, Gao X. (2013). A preliminary experimental study on the cardiac toxicity of glutamate and the role of $\alpha$-amino-3hydroxy-5-methyl-4-isoxazolepropionic acid receptor in rats. Chin Med J (Engl), 126(7), 1323-32.

52. Bozic M, de Rooij J, Parisi E, Ortega MR, Fernandez E, Valdivielso JM. (2011). Glutamatergic signaling maintains the epithelial phenotype of proximal tubular cells. J Am Soc Nephrol, 22(6), 1099-111.

53. Fahlke C, Kortzak D, Machtens JP. (2016). Molecular physiology of EAAT anion channels. Pflugers Arch, 468(3), 491-502.

54. Magi S, Arcangeli S, Castaldo P, Nasti AA, Berrino L, Piegari E, Bernardini R, Amoroso S, Lariccia V. (2013). Glutamate-induced ATP synthesis: relationship between plasma membrane $\mathrm{Na}+/ \mathrm{Ca} 2+$ exchanger and excitatory amino acid transporters in brain and heart cell models. Mol Pharmacol, 84(4), 603-14.

55. Ralphe JC, Segar JL, Schutte BC, Scholz TD. (2004). Localization and function of the brain excitatory amino acid transporter type 1 in cardiac mitochondria. J Mol Cell Cardiol, 37(1), 33-41.

56. Laketić-Ljubojević I, Suva LJ, Maathuis FJ, Sanders D, Skerry TM. (1999). Functional characterization of Nmethyl-D-aspartic acid-gated channels in bone cells. Bone, 25(6), 631-7.
57. Shi S, Liu T, Li Y, Qin M, Tang Y, Shen JY, Liang J, Yang B, Huang C. (2014). Chronic N-methyl-D-aspartate receptor activation induces cardiac electrical remodeling and increases susceptibility to ventricular arrhythmias. Pacing Clin Electrophysiol, 37(10), 1367-77

58. D’Amico M, Di Filippo C, Rossi F, Rossi F. (1999). Arrhythmias induced by myocardial ischaemia-reperfusion are sensitive to ionotropic excitatory amino acid receptor antagonists. Eur J Pharmacol, 366(2-3), 167-74.

59. Sun X, Zhong J, Wang D, Xu J, Su H, An C, Zhu H, Yan J. (2014). Increasing glutamate promotes ischemiareperfusion-induced ventricular arrhythmias in rats in vivo. Pharmacology, 93(1-2), 4-9.

60. $\overline{\text { Gao X }}$, Xu X, Pang J, Zhang C, Ding JM, Peng X, Liu Y, Cao JM. (2007). NMDA receptor activation induces mitochondrial dysfunction, oxidative stress and apoptosis in cultured neonatal rat cardiomyocytes. Physiol Res, 56(5), 559-69.

61. Tyagi N, Vacek JC, Givvimani S, Sen U, Tyagi SC. (2010). Cardiac specific deletion of N-methyl-d-aspartate receptor 1 ameliorates mtMMP-9 mediated autophagy/ mitophagy in hyperhomocysteinemia. J Recept Signal Transduct Res, 30(2), 78-87.

62. Moshal KS, Tipparaju SM, Vacek TP, Kumar M, Singh M, Frank IE, Patibandla PK, Tyagi N, Rai J, Metreveli N, Rodriguez WE, Tseng MT, Tyagi SC. (2008). Mitochondrial matrix metalloproteinase activation decreases myocyte contractility in hyperhomocysteinemia. Am J Physiol Heart Circ Physiol, 295(2), 890-7

63. Meneghini A, Ferreira C, Abreu LC, Valenti VE, Ferreira M, F Filho C, Murad N. (2009). Memantine prevents cardiomyocytes nuclear size reduction in the left ventricle of rats exposed to cold stress. Clinics (Sao Paulo), 64(9), 921-6.

64. Srejovic I, Jakovljevic V, Zivkovic V, Jeremic N, Jevdjevic M, Stojic I, Djuric D. (2015). The effects of glycine, glutamate and their combination on cardiodynamics, coronary flow and oxidative stress in isolated rat heart. Curr Res Cardiol, 2(2), 63-68.

65. Stojic I, Srejovic I, Zivkovic V, Jeremic N, Djuric M, Stevanovic A, Milanovic T, Djuric D, Jakovljevic V. (2017). The effects of verapamil and its combinations with glutamate and glycine on cardiodynamics, coronary flow and oxidative stress in isolated rat heart. J Physiol Biochem, 73(1), 141-153.

66. McCully KS. (1969). Vascular pathology of homocysteinemia: implications for the pathogenesis of arteriosclerosis. Am J Pathol, 56(1), 111-28.

67. Steed MM, Tyagi SC. (2011). Mechanisms of cardiovascular remodeling in hyperhomocysteinemia. Antioxid Redox Signal, 15(7), 1927-43.

68. Pizzolo F, Blom HJ, Choi SW, Girelli D, Guarini P, Martinelli N, Stanzial AM, Corrocher R, Olivieri O, Friso S. (2011). Folic acid effects on s-adenosylmethionine, s-adenosylhomocysteine, and DNA methylation in patients with intermediate hyperhomocysteinemia. J Am Coll Nutr, 30(1), 11-8. 
69. Jakubowski H. (2000). Homocysteine thiolactone: metabolic origin and protein homocysteinylation in humans. J Nutr, 130(2S Suppl), 377-381.

70. Hankey GJ, Eikelboom JW. (1999). Homocysteine and vascular disease. Lancet, 354(9176), 407-13.

71. Herrmann W, Herrmann M, Joseph J, Tyagi SC. (2007). Homocysteine, brain natriuretic peptide and chronic heart failure: a critical review. Clin Chem Lab Med, 45(12), 1633-44.

72. Folbergrová J. (1994). NMDA and not non-NMDA receptor antagonists are protective against seizures induced by homocysteine in neonatal rats. Exp Neurol, 130(2), 344-50.

73. Tyagi N, Mishra PK, Tyagi SC. (2009). Homocysteine, hydrogen sulfide (H2S) and NMDA-receptor in heart failure. Indian J Biochem Biophys, 46(6), 441-6.

74. Chang PY, Lu SC, Lee CM, Chen YJ, Dugan TA, Huang WH, Chang SF, Liao WS, Chen CH, Lee YT. (2008). Homocysteine inhibits arterial endothelial cell growth through transcriptional downregulation of fibroblast growth factor-2 involving $\mathrm{G}$ protein and DNA methylation. Circ Res, 102(8), 933-41.

75. Austin RC, Lentz SR, Werstuck GH. (2004). Role of hyperhomocysteinemia in endothelial dysfunction and atherothrombotic disease. Cell Death Differ, 11 Suppl 1, 56-64.

76. Tyagi N, Sedoris KC, Steed M, Ovechkin AV, Moshal KS, Tyagi SC. (2005). Mechanisms of homocysteine-induced oxidative stress. Am J Physiol Heart Circ Physiol, 89, 2649-56.

77. Kamat PK, Kalani A, Tyagi SC, Tyagi N. (2015). Hydrogen Sulfide Epigenetically Attenuates HomocysteineInduced Mitochondrial Toxicity Mediated Through NMDA Receptor in Mouse Brain Endothelial (bEnd3) Cells. J Cell Physiol, 230(2), 378-94.

78. Srejovic I, Jakovljevic V, Zivkovic V, Barudzic N, Radovanovic A, Stanojlovic O, Djuric DM. (2015). The effects of the modulation of NMDA receptors by homocysteine thiolactone and dizocilpine on cardiodynamics and oxidative stress in isolated rat heart. Mol Cell Biochem, 401(1-2), 97-105. 